\title{
OPTIMAL TEMPERATURES FOR GROWTH AND UPPER THERMAL TOLERANCE OF JUVENILE NORTHERN LEATHERSIDE CHUB
}

\author{
Eric J. Billman ${ }^{1}$, Eric J. Wagner ${ }^{2,3}$, Ronney E. Arndt², and Erin VanDyke ${ }^{2}$
}

\begin{abstract}
AвstraCt.-We examined optimal temperatures for growth and the upper thermal tolerance of juvenile northern leatherside chub (Lepidomeda copei). We conducted 2 experiments using the acclimated chronic-exposure method to estimate optimal temperature for growth of age-0 northern leatherside chub (range $12.8-28.3^{\circ} \mathrm{C}$ ). Upper thermal tolerance was estimated using the critical thermal maximum (CTM) and upper incipient lethal temperature (UILT) methods for fish acclimated at $15,18,23$, and $28^{\circ} \mathrm{C}$. We also measured stream temperatures in Yellow Creek, Summit County, Utah, during July-August 2006 to compare our results to actual summer stream temperatures. Survival in growth tests was not significantly different between treatment temperatures in either experiment $(P>0.098)$. The optimal temperature for growth in the 1st trial estimated from the 2nd-order polynomial regression was $23.0{ }^{\circ} \mathrm{C}$, falling outside the range of experimental temperatures $\left(12.8-22.2^{\circ} \mathrm{C}\right)$. The estimated optimal temperature for growth in the 2 nd trial was $23.2^{\circ} \mathrm{C}$. In the upper thermal tolerance tests, juvenile northern leatherside chub had CTM values between 29.6 and $35.0^{\circ} \mathrm{C}$; CTM values increased as acclimation temperature increased. Upper incipient lethal temperatures $\left(\mathrm{LT}_{50}\right)$ ranged from 26.5 to $30.2^{\circ} \mathrm{C}$, increasing with acclimation temperature. Summer stream temperatures in Yellow Creek had a lower mean $\left(14.0-18.1^{\circ} \mathrm{C}\right)$ than did the optimal temperature for growth determined in these studies, but these temperatures exhibited diel fluctuations as large as $15.7^{\circ} \mathrm{C}$.
\end{abstract}

Key words: leatherside chub, Lepidomeda copei, temperature, critical thermal maximum, UILT, growth efficiency, Plagopterini.

Leatherside chub is a small cyprinid native to streams and rivers in the Bonneville Basin and the upper Snake River drainage of western North America (Sigler and Sigler 1987, Johnson et al. 2004). Recent analyses have indicated that there are 2 distinct taxonomic groups of leatherside chub, a northern group (Lepidomeda copei) and a southern group (Lepidomeda aliciae), which are now considered separate species (Johnson and Jordan 2000, Dowling et al. 2002, Johnson et al. 2004, Belk et al. 2005). Lepidomeda copei populations historically occurred in the Snake River system, the Bear River system (Utah, Wyoming, and Idaho), and in the Little Wood River of Idaho and Wyoming. Numbers of both species of leatherside chub have declined dramatically in the past century due to habitat degradation (e.g., impoundments, dewatering, and siltation) and introduction of nonnative species, particularly brown trout Salmo trutta (Walser et al. 1999, Wilson and Belk 2001, Olsen and Belk 2005). Recent population surveys indicate that declines in northern leatherside chub have left the remaining populations increasingly isolated; as such, northern leatherside chub are considered a "species of concern" in Utah (Wilson and Lentsch 1998, Combes and Hardy 2003, Nadolski and Thompson 2004).

Recent research has provided basic life history information on leatherside chub (Johnson et al. 1995, Walser et al. 1999, Wilson and Belk 2001, Bell and Belk 2004, Quist et al. 2004, Olsen and Belk 2005), but temperature requirements for growth and tolerance to extreme temperatures have not been studied. Temperature is an important habitat component because it affects most biochemical and physiological processes in fishes (Brett 1979). As such, the distribution of stream fishes is partially determined by temperatures required for growth and reproduction, as well as the ability of the fish to tolerate local extremes in temperatures (McHugh and Budy 2005). Similarly, the thermal requirements and tolerances of a species provide information needed for predictions of a species' persistence given changes in stream habitat (Eaton and Scheller 1996, Keleher and Rahel 1996, Widmer et al. 2006).

\footnotetext{
${ }^{1}$ Department of Integrative Biology, Brigham Young University, Provo, UT 84602.

${ }^{2}$ Utah Division of Wildlife Resources, Fisheries Experiment Station, 1465 West 200 North, Logan, UT 84321

${ }^{3}$ Corresponding author. E-mail: ericwagner@utah.gov
} 
TABLE 1. Mean temperatures and age-0 northern leatherside chub survival for each treatment in 2 trials assessing the effects of temperature on growth. Standard deviation is shown in parentheses.

\begin{tabular}{lcc}
\hline Trial & Temperature $\left({ }^{\circ} \mathrm{C}\right)$ & Survival $(\%)$ \\
\hline 1 & $12.8(0.31)$ & $85(13.2)$ \\
& $15.5(0.28)$ & $90(0.0)$ \\
$17.9(0.51)$ & $93(5.8)$ \\
& $19.9(0.66)$ & $95(5.0)$ \\
& $22.2(0.90)$ & $88(7.6)$ \\
2 & $16.6(0.26)$ & $99(2.3)$ \\
& $19.7(0.34)$ & $97(2.3)$ \\
& $22.6(0.39)$ & $96(6.9)$ \\
& $25.3(0.59)$ & $95(2.3)$ \\
& $28.3(0.54)$ & $87(4.6)$ \\
\hline
\end{tabular}

The objectives of this study of age-0 northern leatherside chub were to determine the effects of temperature on growth and survival and to determine an upper temperature tolerance. The acclimated chronic-exposure method (Selong et al. 2001) was used to determine the effects of static temperature on growth and survival of northern leatherside chub and to estimate optimal temperatures for growth. The upper temperature tolerance was determined using both the critical thermal maximum (CTM; Becker and Genoway 1979) and 96-hour upper incipient lethal temperature methods (Fry 1947, Armour 1991).

\section{METHODS}

\section{Effects of Temperature on Growth}

We conducted 2 temperature trials using the acclimated chronic-exposure method with static temperatures at the Utah Division of Wildlife Resources' Fisheries Experiment Station in Logan, Utah. Age-0 northern leatherside chub were produced in summer 2005 using wild broodstock from Deadman Creek, Bear River Drainage, Utah, maintained at the Fisheries Experiment Station. A flow-through system previously described by Billman et al. (2006) was modified for each experiment to achieve test temperatures. Cold well water $\left(14^{\circ} \mathrm{C}\right)$ was mixed with heated warm well water $\left(18{ }^{\circ} \mathrm{C}\right.$ before heating with two $6-\mathrm{kW}, 240-\mathrm{V}$ water heaters) in separate head boxes. Heated water passed through degassing columns prior to mixing. For each temperature, a head box supplied water to three 38-L aquaria; each aquarium served as a replicate for that temperature. Additionally, cold well water was chilled with a water chiller (Pro-cool Titanium Chiller 553030, AREA, Inc., Homestead, FL) to reach the lowest test temperature in the 1st trial. Mean flow rate into each replicate was 1.2 and $1.6 \mathrm{~L}$ - $\mathrm{min}^{-1}$ for the 1st and 2 nd trials, respectively. We used a temperature logger $\left(\mathrm{Hobo}^{\circledR}\right.$ Water Temp Pro), which recorded temperature every 3 hours, to monitor water temperature from 1 replicate within each treatment. On a weekly basis, temperature data were downloaded and the loggers were rotated among the 3 replicates within a treatment. All aquaria and connecting pipes were covered with insulation to minimize temperature fluctuations. Temperatures were maintained throughout each trial with minimal fluctuations (Table 1). Full-spectrum fluorescent lights provided a $14 \mathrm{~h}: 10 \mathrm{~h}$ (light:dark) photoperiod for the 1st study, and a 10h:14h (light:dark) photoperiod for the 2nd study. The different photoperiods were used to simulate natural conditions.

Fish were fed a diet of ground commercial flake feed $\left(\right.$ TetraMin $\left.{ }^{\circledR}\right)$. The fish were fed 3 times daily during the workweek and twice daily on the weekends; regardless of the day, each replicate received $8 \%$ of the total fish biomass daily. This was a relatively large amount of feed, but we wanted to ensure that fish in all treatments were fed to excess, so that feed was not a limiting factor. Additionally, we supplemented the diet with brine shrimp (Artemia franciscana) nauplii (44 mg once daily) that we had frozen in ice cubes. For the 1st portion of each study, the feed ration was adjusted weekly, based on our assumption of a 3\% daily increase in biomass. On days 26 and 51 of the 1st study and days 27 and 54 of the 2 nd study, the weight of fish from each replicate was measured by placing all fish into a preweighed beaker of water, measuring the increase in total weight, and dividing by the number of fish. Specific growth rate $\left(\mathrm{SGR}=\left[\left(\log _{\mathrm{e}}\right.\right.\right.$ weight $_{\text {final }}-\log _{\mathrm{e}}$ weight $\left._{\text {initital }}\right) /($ number of days $\left.)\right] \cdot 100$ ) was estimated for each replicate after each sample date and used to adjust the weekly feed ration for the weeks following the sample. Mortalities were removed daily, and total length and weight of these individuals were measured.

In the 1st trial, growth and survival of age0 northern leatherside chub were measured over a 76-day period at the following test temperatures: $12.8,15.5,17.9,19.9$, and $22.2{ }^{\circ} \mathrm{C}$ (Table 1). The upper temperature was based 
on mean summer temperatures observed in streams where adult northern leatherside chub exist (Belk et al. 2005). After hatching on 9 August 2005, age- 0 L. copei were held in $18{ }^{\circ} \mathrm{C}$ well water, until 15 September, after which water temperature was lowered to $16.5^{\circ} \mathrm{C}$. On 28 September, twenty 50-day old fish were randomly selected and placed into each aquarium. Initial weights for fish within each tank were obtained using the methods described above. Fish averaged $69.7 \mathrm{mg}$, and there was no significant difference $(P=0.464)$ in mean individual weights among treatments. The fish were transferred directly into aquaria that were already at treatment temperatures, allowing no time for acclimation. However, the largest temperature change was only $5.7^{\circ} \mathrm{C}$, and no fish showed evidence of thermal shock due to the rapid change. Fish were held at test temperatures for 76 days to simulate the duration of exposure to the potentially high or low seasonal temperatures (Selong et al. 2001). After the 76 days, we measured the weight of the fish in each replicate as above and estimated specific growth rate over the entire time period.

The 2nd trial was conducted because lack of growth inhibition at the highest temperature in the 1st trial indicated that we had not adequately bracketed the temperatures for optimal growth. In the 2nd trial, growth and survival of age-0 northern leatherside chub were measured over a 79-day period at the following test temperatures: 16.6, 19.7, 22.6, 25.3, and $28.3^{\circ} \mathrm{C}$ (Table 1). Age-0 fish for the trial were initially held in $18{ }^{\circ} \mathrm{C}$ well water until 29 September 2005, after which water temperature was lowered to $15.6{ }^{\circ} \mathrm{C}$. On 20 December, twenty-five 105-108-day-old fish were randomly selected and placed into each of the 3 replicates for the 16.6 and $19.7^{\circ} \mathrm{C}$ treatments, and 225 were placed into the $22.6^{\circ} \mathrm{C}$ treatment aquaria. The following day, the 225 northern leatherside chub that had been in the $22.6{ }^{\circ} \mathrm{C}$ treatment were randomly distributed into the remaining replicates for the warmer treatments. This was done to provide the fish at the warmest temperatures with at least a short acclimation period rather than a rapid $12.6{ }^{\circ} \mathrm{C}$ temperature change. As with the 1st trial, no fish showed evidence of thermal shock. Initial weights of the fish (measured using methods described above) were not significantly different among treatments $(P>0.441)$; fish averaged $176.2 \mathrm{mg}$. Fish were held at their assigned temperatures for 79 days, after which final weight was measured and specific growth rate estimated for each replicate.

For each trial, differences in specific growth rates among temperatures were compared via a one-way ANOVA. Post hoc comparisons were conducted with Tukey's test. Optimal temperature range for growth was determined for each study by fitting the data (mean specific growth rate per tank and temperature) to a 2 nd-order polynomial regression. The optimal temperature, or temperature for maximum growth, was estimated by setting the 1st derivative of the regression equation equal to zero (Selong et al. 2001). Differences in percent survival among temperatures were analyzed using the KruskalWallis test because the data did not meet assumptions of normality. SPSS version 13 (SPSS 2004) was used for all analyses, and $\alpha$ $=0.05$ for significance determinations.

\section{Upper Temperature Tolerance}

Upper temperature tolerance was estimated using the critical thermal maximum method (CTM) and the upper incipient lethal temperature (UILT) method (Cowles and Bogert 1944, Paladino et al. 1980, Armour 1991). Each of the temperature tolerance tests has its own strengths and weaknesses, and interpretation of the data is slightly different for each test (Beitinger et al. 2000). The CTM method (Cowles and Bogert 1944) has been useful for comparing relative thermal tolerance among species or even among populations of the same species (Kowalski et al. 1978, Becker and Genoway 1979, Matthews 1986), as well as documenting sublethal effects of pollutants (Watenpaugh and Beitinger 1985, Carrier and Beitinger 1988). The test requires less time to conduct than the UILT, but the estimates of thermal tolerance are typically higher because chronic temperature effects are not evaluated (Lohr et al. 1996, Wagner et al. 2001). The UILT method (Fry 1947, 1967) has been used to establish upper thermal limits for many species (Tyler 1966, Cook et al. 2006). It is considered a more accurate estimate of thermal tolerance under natural conditions (Paladino et al.1980). However, even UILT values are only general guidelines given that temperature fluctuations and chronic temperature effects may result in slightly differing thermal maxima (Wehrly et al. 2007). For reviews of the methods see Brungs and Jones (1977), Paladino et 
al. (1980), Armour (1991), Lutterschmidt and Hutchison (1997), and Beitinger et al. (2000).

We used $\mathrm{F} 1$ progeny from northern leatherside chub raised at the Fisheries Experiment Station from 2 wild sources within the Bear River drainage of Utah and Wyoming: Deadman Creek and Yellow Creek. The fish were divided into 4 groups reared at different acclimation temperatures: $15.0 \pm 0.6{ }^{\circ} \mathrm{C}, 18.0 \pm 1.0$ ${ }^{\circ} \mathrm{C}, 23.0 \pm 1.1{ }^{\circ} \mathrm{C}$, and $28.0 \pm 1.5{ }^{\circ} \mathrm{C}$. There were 3 aquaria for each acclimation temperature: 2 with Deadman Creek progeny and 1 with Yellow Creek progeny. They remained in the acclimation tanks for at least 50 (CTM tests) to 57 days (UILT tests) prior to tests.

Temperatures $>15{ }^{\circ} \mathrm{C}$ were achieved by heating well water in a separate raceway with immersion heaters. The heated water was degassed in a 1.5-m column of Koch rings and plumbed to head boxes where it was mixed with the $15{ }^{\circ} \mathrm{C}$ water to achieve the target temperatures. Total hardness, measured as $\mathrm{CaCO}_{3}$ content, of the well water was $222 \mathrm{mg} \cdot \mathrm{L}^{-1}$. Prior to the tests, fish were fed 3-4 times daily (1-2 times daily on weekends) with TetraMin ${ }^{\circledR}$ flake feed and supplemented with frozen Artemia nauplii several times per week.

For CTM tests, fish were randomly selected and tested individually. Five or more fish from each source were tested, totaling at least 10 fish from each acclimation temperature. Fish were placed in a 4.0-L Erlenmeyer flask containing $3.0 \mathrm{~L}$ of water from the acclimation tank. Temperature was increased at a constant rate of $0.2{ }^{\circ} \mathrm{C} \cdot \mathrm{min}^{-1}$ on a laboratory hot plate, similar to the rate recommended by Becker and Genoway (1979). Uniform temperature was maintained in the flask by a magnetic stir bar. The water was stirred slowly enough so that fish did not have to swim against a current while uniform temperature was being maintained. Temperature was recorded every 10 minutes with a digital probe that was suspended off the bottom of the flask, and the change in temperature was calculated between the 10-minute intervals. Time and temperature was recorded when the fish lost equilibrium, whereupon the test was concluded. Dissolved oxygen (DO) was recorded at the end of the test. The average weights of the fish tested were $0.35 \mathrm{~g}$ for Deadman Creek fish and 0.27 $\mathrm{g}$ for Yellow Creek fish.

For the UILT tests, northern leatherside chub from each of the acclimation temperatures were challenged in 4 separate tests ( 1 test per acclimation temperature) with high temperatures over a 96-hour period. For each test there were 3-4 challenge temperatures ranging from 17 to $32^{\circ} \mathrm{C}$, as well as a control at the acclimation temperature. There were 3 replicate buckets per challenge temperature (12-15 buckets total) with 10 fish in each bucket. Mortality rates were determined for each 26-L bucket. Fish for the study were a mix of juveniles from both Deadman Creek and Yellow Creek parental origins. To achieve the challenge temperature, a 200-watt aquarium heater (Jäger, Plochinger, Germany) was put in each bucket. A small water pump in each bucket kept the water mixed and ensured that a uniform temperature was maintained. Fish were transferred directly from the acclimation tank to the preheated test tank.

Fish were not fed during the 96-hour period and no water exchanges were conducted. In some of the highest challenge temperatures, up to a liter of water was added to compensate for evaporation and maintain water levels for proper functioning of the heater thermostat. Water temperatures were measured at least every 2 hours and DO was measured once daily with a calibrated probe. Any mortalities were removed and counted as they occurred. Total length and weight measurements were taken on dead fish when they were removed and also on survivors at the end of each test. When tests were concluded, DO was measured, as well as $\mathrm{pH}$ (Orion meter) and total alkalinity (Hach Chemical Co. kit, Loveland, CO). Carbon dioxide concentrations were estimated using total alkalinity, $\mathrm{pH}$, and temperature data (Boyd 1990).

A general linear model with acclimation temperature and fish source as fixed variables was used to analyze differences in CTM values. The least significant difference test was used for subsequent mean comparisons. Probit analysis was used to estimate the temperature that was lethal to $50 \%$ of the fish at a given acclimation temperature within the UILT tests. Mean length and weight were tested for normality using the Kolmogorov-Smirnov and ShapiroWilkes tests (SPSS 2004). A $t$ test was used to compare mean length and weight between mortalities and survivors within each test.

\section{Summer Stream Temperatures}

We recorded water temperature at 3 sites in Yellow Creek, Summit County, Utah, where 


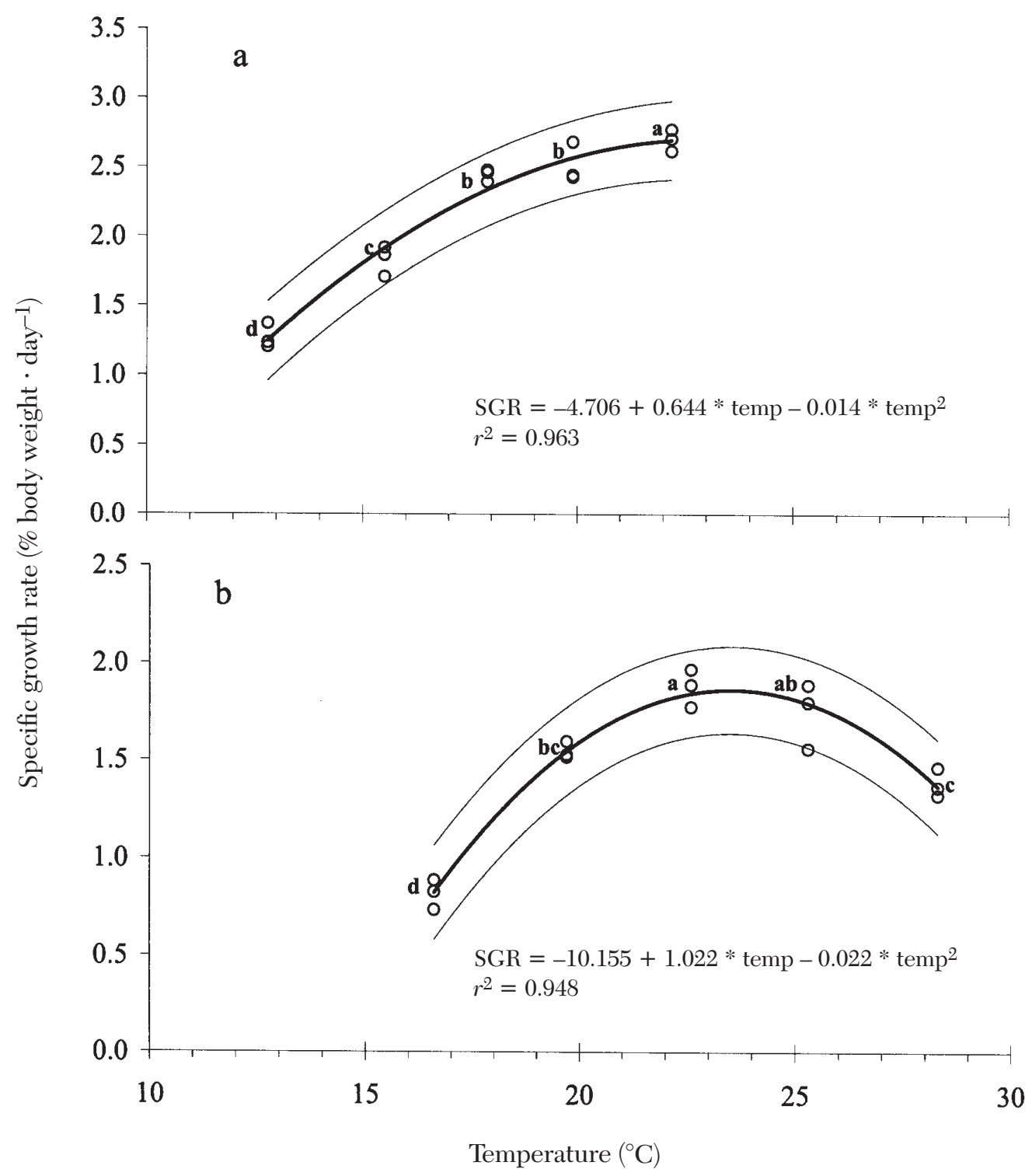

Fig. 1. Specific growth rate of northern leatherside chub in relation to temperature as determined for temperature trial 1 (a) and temperature trial 2 (b). Each circle represents the mean individual weight gain of fish for each tank at each treatment temperature. Hairlines indicate the $95 \%$ confidence limits of the regression line. The correlation coefficients of the regressions are also presented. Letters indicate significant $(\alpha=0.05)$ differences in specific growth rate among temperatures for each study.

populations of northern leatherside chub are known to exist, to compare the results of the laboratory studies to actual stream temperatures that the northern leatherside chub encounters. Yellow Creek is a small, high-elevation (2000-2500 m) stream tributary to the Bear River. It has a native fish community typical for the region and does not contain any nonna- tive species. The elevation of this stream is similar to streams in other drainages where northern leatherside chub have been documented (Quist et al. 2004). The upstream-most site (site 1) was $5.7 \mathrm{~km}$ from Yellow Creek's source and represents the upstream limit for northern leatherside chub (Nadolski and Thompson 2004). Site 2 was $5 \mathrm{~km}$ downstream 
TABLE 2. Mean $(n=5)$ critical thermal maximums $\left({ }^{\circ} \mathrm{C}\right)$ for 2 sources of northern leatherside chub when the fish are acclimated to different temperatures. Standard deviation is shown in parenthese. A common letter follows the means that are not significantly different within a row.

\begin{tabular}{lllll}
\hline & \multicolumn{4}{c}{ Acclimation temperature $\left({ }^{\circ} \mathrm{C}\right)$} \\
\cline { 2 - 4 } Source & \multicolumn{1}{c}{15.0} & 18.0 & 23.0 & 28.0 \\
\hline Deadman Creek & $29.5(0.4) \mathrm{a}$ & $32.0(0.5) \mathrm{b}$ & $34.6(0.4) \mathrm{c}$ & $35.1(0.8) \mathrm{c}$ \\
Yellow Creek & $29.7(0.4) \mathrm{a}$ & $31.7(0.2) \mathrm{b}$ & $34.6(0.4) \mathrm{c}$ & $34.9(0.6) \mathrm{c}$ \\
Average & $29.6(0.4)$ & $31.8(0.4)$ & $34.6(0.4)$ & $35.0(0.7)$ \\
\hline
\end{tabular}

TABLE 3. Average cumulative percent mortality $(n=3)$ over 96 hours for northern leatherside chub after being transferred from a given acclimation temperature to a challenge temperature. Also given is the lethal temperature $\left(\mathrm{LT}_{50}\right)$ at which $50 \%$ of the 10 experimental fish are estimated to die within a 96-hour exposure.

\begin{tabular}{|c|c|c|c|c|c|c|c|c|c|c|c|}
\hline \multirow[b]{2}{*}{$\begin{array}{l}\text { Acclimation } \\
\text { temperature }\left({ }^{\circ} \mathrm{C}\right)\end{array}$} & \multicolumn{10}{|c|}{ Challenge temperature $\left({ }^{\circ} \mathrm{C}\right)$} & \multirow[b]{2}{*}{$\mathrm{LT}_{50}\left({ }^{\circ} \mathrm{C}\right)$} \\
\hline & 17.0 & 18.0 & 23.0 & 26.0 & 27.0 & 28.0 & 29.0 & 30.0 & 31.0 & 32.0 & \\
\hline 15.0 & 0 & & & 10.0 & 89.0 & 94.0 & 100 & & & & 26.5 \\
\hline 18.0 & & 0 & & 6.7 & 30.0 & 10.0 & 75.5 & & & & 28.7 \\
\hline 23.0 & & & 6.6 & & & 3.3 & 20.0 & 23.3 & 100 & & 30.4 \\
\hline 28.0 & & & & & & 0 & & 38.9 & 100 & 100 & 30.2 \\
\hline
\end{tabular}

from site 1 , while site 3 was $35 \mathrm{~km}$ downstream, below Barker Reservoir. From 22 July to 24 August 2006, temperature loggers at the 3 sites recorded temperature every 30 minutes. We calculated mean, minimum, and maximum temperatures at each site, as well as mean and maximum diel temperature change.

\section{RESUlts}

\section{Effects of Temperature on Growth}

In the 1st trial, specific growth rate was significantly different among treatments, except at 17.9 and $19.9{ }^{\circ} \mathrm{C}$, with specific growth rate being higher at warmer temperatures $\left(F_{4,14}=\right.$ 109.12, $P<0.001$; Fig. 1). The highest specific growth rate observed was at the highest temperature $\left(22.2^{\circ} \mathrm{C}\right)$. However, the optimal temperature for growth as predicted from the 2nd-order polynomial regression $\left(23.0^{\circ} \mathrm{C}\right)$ was outside the range of temperatures used in this trial. The survival of northern leatherside chub ranged from $85 \%$ at $12.8^{\circ} \mathrm{C}$ to $95 \%$ at $19.9{ }^{\circ} \mathrm{C}$ and was not significantly different among temperature treatments $\left(H_{4}=2.893, P=0.576\right.$; Table 1).

In the 2nd trial, specific growth rate was significantly different among treatments $\left(F_{4,14}\right.$ $=50.039, P<0.001$; Fig. 1). Specific growth rate was significantly lower in the $16.6{ }^{\circ} \mathrm{C}$ treatment compared to other temperatures, while it was significantly higher in the 22.6 and $25.3{ }^{\circ} \mathrm{C}$ treatments (not significantly different from each other) compared to the other treatments. The optimal temperature for maximum growth was estimated to occur at $23.2{ }^{\circ} \mathrm{C}$ using the 2nd-order polynomial regression. The survival of northern leatherside chub was not significantly different among temperature treatments $\left(H_{4}=7.829, P=0.098\right.$; Table 1$)$, ranging from $87 \%$ at $28.3^{\circ} \mathrm{C}$ to $99 \%$ at $16.6^{\circ} \mathrm{C}$.

\section{Upper Thermal Tolerance}

Mean CTM values significantly increased from 29.6 to $35.0^{\circ} \mathrm{C}$ as the acclimation temperature increased $(P<0.001$; Table 2$)$. There was no significant difference in the CTM values between the 2 stream sources at all acclimation temperatures $(P=0.644)$.

UILT increased as acclimation temperature increased. Values indicated that 30.2 to $30.3^{\circ} \mathrm{C}$ is the ultimate upper incipient thermal limit that northern leatherside chub can tolerate (Table 3). Probit analysis indicated that $\mathbf{L T}_{50}$ values ranged from 26.5 to $30.3{ }^{\circ} \mathrm{C}$, generally increasing as acclimation temperatures increased (Table 3). At lower acclimation temperatures, an increase of greater than $10-12{ }^{\circ} \mathrm{C}$ led to significant mortality. Within individual tests, only in the $18{ }^{\circ} \mathrm{C}$ acclimation temperature trial was length significantly longer for live fish than for dead fish $(P=0.022)$; total fish length in all other tests did not significantly differ between live and dead fish. Mean weight was significantly greater for dead fish than for 
TABLE 4. Range of values in water quality parameters for 96-hour UILT tests among all tanks for a given acclimation temperature trial.

\begin{tabular}{lcccc}
\hline & \multicolumn{3}{c}{ Acclimation temperature $\left({ }^{\circ} \mathrm{C}\right)$} \\
\cline { 2 - 5 } & 15.0 & 18.0 & 23.0 & 28.0 \\
\hline Carbon dioxide $\left(\mathrm{mg} \cdot \mathrm{L}^{-1}\right)$ & $32.8-45.1$ & $36.9-45.1$ & $28.7-41.0$ & $37.0-41.0$ \\
Dissolved oxygen $\left(\mathrm{mg} \cdot \mathrm{L}^{-1}\right)$ & $7.4-10.0$ & $7.2-10.0$ & $6.7-8.5$ & $7.2-8.2$ \\
Total un-ionized $\mathrm{NH}_{3}\left(\mathrm{mg} \cdot \mathrm{L}^{-1}\right)$ & $0.001-0.014$ & $0.001-0.095$ & $0.020-0.170$ & $0.0005-0.012$ \\
$\mathrm{pH}$ & $8.2-8.5$ & $8.1-8.4$ & $8.1-8.3$ & $7.9-8.3$ \\
\hline
\end{tabular}

TABLE 5. Summary of elevation and water temperatures $\left({ }^{\circ} \mathrm{C}\right)$ from 3 sites in Yellow Creek, Utah, 22 July to 24 August 2006. Sites are ordered upstream to downstream (see text for site descriptions).

\begin{tabular}{lcccc}
\hline Site & Elevation $(\mathrm{m})$ & $\begin{array}{c}\text { Mean } \\
\text { temperature (range) }\end{array}$ & $\begin{array}{c}\text { Mean diel } \\
\text { temperature change }\end{array}$ & $\begin{array}{c}\text { Maximum diel } \\
\text { temperature change }\end{array}$ \\
\hline Site 1 & 2405 & $14.1^{\circ} \mathrm{C}(7.0-25.0)$ & 10.4 & 13.7 \\
Site 2 & 2295 & $17.3^{\circ} \mathrm{C}(9.3-28.7)$ & 11.8 & 15.7 \\
Site 3 & 2100 & $18.0^{\circ} \mathrm{C}(11.0-27.1)$ & 9.5 & 12.6 \\
\hline
\end{tabular}

live fish in the $15{ }^{\circ} \mathrm{C}$ acclimation temperature trial $(P=0.004)$ but did not significantly differ between live and dead fish in the other 3 tests.

Water quality for each of the tests indicated that values for these parameters were within ranges that should not have led to mortality (Table 4). All control fish survived the treatments with the exception of a few fish $(6 \%)$ in the $23{ }^{\circ} \mathrm{C}$ acclimation temperature trial.

\section{Summer Stream Temperatures}

Stream temperature fluctuated greatly at all sites (Table 5). Mean daily temperatures ranged from 14.1 to $18.0{ }^{\circ} \mathrm{C}$ and were cooler upstream and warmer downstream. The difference between the monthly maximum and minimum temperatures ranged from 16.1 to $19.4^{\circ} \mathrm{C}$, with a maximum temperature at any site of $28.7^{\circ} \mathrm{C}$ and a minimum temperature of $7.0{ }^{\circ} \mathrm{C}$. The mean diel temperature fluctuations ranged from 9.5 to $11.8^{\circ} \mathrm{C}$, with the maximum diel fluctuation being $15.7^{\circ} \mathrm{C}$. Juvenile and adult northern leatherside chub were observed at each site when temperature loggers were set and retrieved.

\section{Discussion}

Many western fish species have broad thermal tolerances because of the environment in which they live (Sigler and Sigler 1987). Arid summers and cold winters cause large seasonal variation in stream temperature, and large diel temperature fluctuations, particularly during summers, are also typical in western streams (Schrank et al. 2003, this study). Age-0 northern leatherside chub demonstrated broad thermal tolerances in these studies. While the optimal temperature for growth was estimated at $23.2{ }^{\circ} \mathrm{C}$, age- 0 northern leatherside chub had positive growth and similar survival over a wide range of temperatures $\left(12.8-28.3^{\circ} \mathrm{C}\right)$. Upper thermal tolerance tests indicated that northern leatherside chub can tolerate temperatures as high as $30^{\circ} \mathrm{C}$ for short periods (96 hours) and higher temperatures $\left(35.0^{\circ} \mathrm{C}\right)$ for shorter periods.

The 2 studies examining the effect of temperature on growth predicted similar optimal temperatures for growth $\left(23.0\right.$ and $23.2^{\circ} \mathrm{C}$ from the 1st and 2nd trials, respectively). However, the specific growth rates from the 1st trial were much faster than those observed in the 2nd trial. The differences in specific growth rates between trials might be attributed to season; the 2 nd growth trial was done during the winter months, and fish were exposed to a winter photoperiod but summer temperatures. However, the specific growth rate differences were more likely due to the difference in fish size between the 2 trials. Fish weight has been shown to have a negative relationship with specific growth rate (Elliott 1975, Ricker 1979, Elliott et al. 1995). This relationship is characterized by an exponential curve such that growth rates decrease markedly for small fish but decrease more slowly for large fish. In the 2nd trial, northern leatherside chub were initially almost 3 times larger than those used in the 1st trial, and this difference in size resulted in an approximately $37 \%$ reduction in 
the predicted maximum growth rate $(2.70 \%$ per day for the 1st trial and $1.71 \%$ per day for the 2 nd trial; Fig. 1). This is similar to the percent decrease in growth reported for stone loach (Barbatula barbatula); growth rates for stone loach decreased by approximately 33\% with a tripling in weight (Elliott et al. 1996). Thus, the differences in specific growth rates between the trials are most probably due to differences in the size of the fish used in each trial.

Mean daily temperatures in streams where northern leatherside chub occur are lower (11.4-18.0 ${ }^{\circ} \mathrm{C}$; Quist et al. 2004, Belk et al. 2005, this study) than the optimal temperatures for growth, although positive growth was achieved in the studies at the reported stream temperatures. Growth of age-0 fish would be reduced in these lower temperatures, possibly limiting recruitment; the size of juvenile fish affects their ability to escape predation and to avoid overwinter mortality, thus affecting year class strength and species persistence (Shuter and Post 1990, Mills 1991, Durham and Wilde 2005). While mean daily temperatures are lower than optimal growth temperatures, diel fluctuations in stream temperature likely play a key role in the growth of northern leatherside chub. In Yellow Creek, stream temperatures during the diel cycle generally encompassed all temperatures used in the growth study, temperatures at which juveniles experienced positive growth rates and no significant decrease in survival. Daily peak temperatures may have a beneficial effect on growth that enables fish to grow at rates higher than expected for mean daily temperatures (Brett 1979, Jobling 1994, Angilletta 2001). For example, Allen et al. (2006) found that juvenile green sturgeon Acipenser medirostris had similar growth rates at both a cyclical temperature regime of $21.5 \pm 2.5^{\circ} \mathrm{C}$ and a constant temperature of $24{ }^{\circ} \mathrm{C}$. Thus, juvenile northern leatherside chub could experience growth rates similar to those demonstrated in these studies in streams with low mean summer temperatures but with diel fluctuations that overlap optimal growth temperatures.

Laboratory growth studies often predict higher growth rates at a given temperature than those actually observed in the field (Brett 1979). For example, Edwards et al. (1979) observed that growth rates of brown trout in the wild were $60 \%-90 \%$ of the predicted maximum for a given temperature based on laboratory studies. The discrepancies between laboratory and field growth rates likely represent the energetic costs fish face when addressing environmental constraints in the field that are absent in a laboratory setting. Fish in laboratory studies such as ours are generally fed to excess. In the wild, fish are likely to encounter variations in prey availability or quality that will result in food limitations. Reductions in ration size result in a decrease in the temperature at which maximum growth rates can be achieved (Brett 1979, Allen and Wootton 1982, Cui and Wootton 1988). Additionally, fish could experience decreased growth rates as a result of energetic costs from competition (aggressive interactions or competitive exclusion from optimal prey or foraging habitat; Mills et al. 2004) and from predator avoidance (increased activity or differential habitat utilization; Werner and Hall 1988). The combination of these environmental constraints can lead to discrepancies between laboratory and field growth rates.

Northern leatherside chub demonstrated the ability to extend their upper thermal tolerance limits with acclimation to higher temperatures. This adaptation is common in many species (Loeb and Wasteneys 1912, Brett 1946, Allen and Strawn 1971). The ability to extend thermal tolerance limits is likely a response to large fluctuations in seasonal temperatures, as many fish species exhibit seasonal changes in thermal tolerance limits (Hoar 1956, Tyler 1966, Kowalski et al. 1978). The result is that the thermal tolerance endpoints bracket seasonal water temperatures fish will encounter (Beitinger and Bennett 2000).

Body size did not affect thermal tolerance in most of the tests in this study, similar to observations made by others (Smale and Rabeni 1995, Carline and Machung 2001, Wagner et al. 2001, Ospina and Mora 2004). However, if the heating rate is too fast or too slow, size may influence thermal tolerance (Cox 1974). Rodnick et al. (2004) noted that while size did not affect critical thermal maximum values, larger fish incurred higher metabolic costs at higher temperatures and were more thermally sensitive than smaller fish.

Latitudinal gradients in temperature produce consistent patterns affecting physiological characteristics, such as growth, in fishes and other ectotherms (Belk and Houston 2002, Belk et al. 2005). Among closely related or sibling 
species, we would predict upper thermal tolerance to follow a model of local adaptation to thermal regime; that is, species at lower latitudes would have higher upper thermal limits than species at higher latitudes, because species at lower latitudes are exposed to higher temperatures for a longer duration (Levinton 1983, Petricorena and Somero 2007). While upper thermal tolerance limits are not available for southern leatherside chub, these limits are available for 3 species from within the Plagopterini tribe, all found in the lower Colorado River drainage (Dowling et al. 2002, Johnson et al. 2004). Both Virgin spinedace (Lepidomeda mollispinis) and woundfin (Plagopterus argentissimus) from the Virgin River had higher mean CTM values $\left(37.0\right.$ and $39.5{ }^{\circ} \mathrm{C}$, respectively, at $25{ }^{\circ} \mathrm{C}$ acclimation temperature; Deacon et al. 1987) compared to northern leatherside chub (CTM of $35.0^{\circ} \mathrm{C}$ at $28{ }^{\circ} \mathrm{C}$ acclimation temperature). Similarly, spikedace (Meda fulgida) from the Gila River had an estimated CTM value of $36.02{ }^{\circ} \mathrm{C}$ at $28^{\circ} \mathrm{C}$ acclimation temperature, estimated using the acclimation response ratio reported by Carveth et al. (2006). Thus, upper thermal tolerance limits in plagopterins appear to support the model of local adaptation to thermal regime for some species.

Native aquatic species of western North America have declined because of stream alterations such as groundwater pumping, channel straightening, loss of nursery habitat, diversion of water for irrigation, siltation, and introduction of nonnative competitors or predators (Berkman and Rabeni 1987, Minckley and Douglas 1991, Olsen and Belk 2005). These alterations, particularly groundwater pumping and diversion of water for irrigation, have diminished surface flows, leading to a loss of riparian vegetation, stream-channel drying, and a subsequent increase in stream temperatures. The stress of high temperatures can have serious effects on native species by reducing available habitat and limiting recruitment to populations (Deacon et al. 1987, Modde et al. 2001, Robinson and Childs 2001, Carveth et al. 2006). Data on the thermal requirements for growth and the thermal tolerances of northern leatherside chub can help guide the management of this species, particularly in stream management decisions, range expansion, and fish transfer. The data suggest that if stream temperatures exceed $29-30{ }^{\circ} \mathrm{C}$, significant mortality of leatherside chub will occur. However, the values are not absolute and must be considered with the variables noted above, such as ration level, fluctuations in temperature (Otto 1974, Carveth et al. 2007), and environmental contaminants (Takle et al. 1983).

\section{ACKNOWLEDGMENTS}

This research was financially supported by the Utah Division of Wildlife Resources and the Utah Reclamation Mitigation and Conservation Commission. Paul Thompson helped collect temperature data in Yellow Creek. We thank Cody Allen for his help in acquiring articles cited in this manuscript.

\section{Literature Cited}

Allen, J.R.M., And R.J. Wootton. 1982. The effect of ration and temperature on the growth of the threespined stickleback, Gasterosteus aculeatus L. Journal of Fish Biology 21:537-547.

Allen, K.O., AND K. STRAWN. 1971. Rate of acclimation of juvenile channel catfish, Ictalurus punctatus, to high temperatures. Transactions of the American Fisheries Society 100:665-671.

Allen, P.J., M. Nicholl, S. Cole, A. Vlazny, and J.J. CECH, JR. 2006. Growth of larval to juvenile green sturgeon in elevated temperature regimes. Transactions of the American Fisheries Society 135:89-96.

Angilletta, M.J., JR. 2001. Thermal and physiological constraints on energy assimilation in a widespread lizard (Sceloporus undulatus). Ecology 82:3044-3056.

Armour, C.L. 1991. Guidance for evaluating and recommending temperature regimes to protect fish. Biological Report 90 (22), Instream Flow Information Paper 27. U.S. Department of the Interior, Washington, DC. 13 pp.

Becker, C.D., and R.G. Genoway. 1979. Evaluation of the critical thermal maximum for determining thermal tolerance of freshwater fish. Environmental Biology of Fishes 4:245-256.

Beitinger, T.L., AND W.A. Bennetr. 2000. Quantification of the role of acclimation temperature in temperature tolerance of fishes. Environmental Biology of Fishes 58:277-288.

Beitinger, T.L., W.A. Bennett, and R.W. McCauley. 2000. Temperature tolerances of North American freshwater fishes exposed to dynamic changes in temperature. Environmental Biology of Fishes 58: $237-275$.

BelK, M.C., and D.D. Houston. 2002. Bergmann's rule in ectotherms: a test using freshwater fishes. American Naturalist 160:803-808.

Belk, M.C., J.B. Johnson, K.W. Wilson, M.E. SMith, AND D.D. Houston. 2005. Variation in intrinsic individual growth rate among populations of leatherside chub (Snyderichthys copei Jordan and Gilbert): adaptation to temperature or length of growing season? Ecology of Freshwater Fish 14:177-184.

Bell, A., AND M.C. Belk. 2004. Diet of the leatherside chub, Snyderichthys copei, in the fall. Western North American Naturalist 64:413-416. 
Berkman, H.E., and C.F. Rabeni. 1987. Effect of siltation on stream fish communities. Environmental Biology of Fishes 18:285-294.

Billman, E.J., E.J. Wagner, and R.E. Arndt. 2006. Effects of temperature on the survival and growth of age-0 least chub (Iotichthys phlegethontis). Western North American Naturalist 66:434-440.

BoYD, C.E. 1990. Water quality in ponds for aquaculture. Alabama Agricultural Experiment Station, Auburn University, AL. 482 pp.

BRETT, J.R. 1946. Rate of gain of heat-tolerance in goldfish (Carassius auratus). Publications of the Ontario Fisheries Research Laboratory No. 64. University of Toronto Studies, Biological Series No. 53. University of Toronto Press, Toronto, Ontario, Canada.

1979. Environmental factors and growth. Pages 599-675 in W.S. Hoar, D.J. Randall, and J.R. Brett, editors, Fish physiology. Volume 8, Bioenergetics and growth. Academic Press, New York. 786 pp.

BRungs, W.A., AND B.R. JonEs. 1977. Temperature criteria for freshwater fish: protocols and procedures. EPA-600/3-77-061. U.S. Environmental Protection Agency Environmental Research Laboratory, Duluth, MN. 129 pp.

Carline, R.F., and J.F. Machung. 2001. Critical thermal maxima of wild and domestic strains of trout. Transactions of the American Fisheries Society 130:12111216.

Carrier, R., AND T.L. Beitinger. 1988. Reduction in thermal tolerance of Notropis lutrensis and Pimephales promelas exposed to cadmium. Water Research 22: $511-515$.

Carveth, C.J., A.M. Widmer, and S.A. Bonar. 2006. Comparison of upper thermal tolerances of native and nonnative fish species in Arizona. Transactions of the American Fisheries Society 135:1433-1440.

Carveth, C.J., A.M. Widmer, S.A. Bonar, and J.R. Simms. 2007. An examination of the effects of chronic static and fluctuating temperature on the growth and survival of spikedace, Meda fulgida, with implications for management. Journal of Thermal Biology 32:102108.

Combes, M., and T. HaRdy. 2003. Fish community structure and habitat in the lower and middle Sevier River Basin. Final Report for the Consolidated Sevier Bridge Reservoir Company and the Utah Division of Wildlife Resources. Institute for Natural Systems Engineering, Utah State University, Logan.

Cook, A.M., J. Duston, And R.G. Bradford. 2006. Thermal tolerance of a northern population of striped bass Morone saxatilis. Journal of Fish Biology 69: 1482-1490.

Cowles, R.B., AND C.M. Bogert. 1944. A preliminary study of the thermal requirements of desert reptiles. Bulletin of the American Museum of Natural History 83:261-296.

Cox, D.K. 1974. Effects of three heating rates on the critical thermal maximum of bluegill. Pages 158-163 in J.W. Gibbons and R.R. Sharitz, editors, Thermal ecology. U.S. Atomic Energy Commission CONF730505 .

Cui, Y., AND R.J. WoOTTON. 1988. Bioenergetics of growth of a cyprinid, Phoxinus phoxinus (L.): the effect of ration and temperature on growth rate and efficiency. Journal of Fish Biology 33:763-773.

Deacon, J.E., P.B. Schumann, and E.L. Stuenkel. 1987. Thermal tolerances and preferences of fishes of the
Virgin River system (Utah, Arizona, Nevada). Great Basin Naturalist 47:538-546.

Dowling, T.E., C.A. Tibbets, W.L. Minckley, and G.R. SмIтн. 2002. Evolutionary relationships of the plagopterins (Teleostei: Cyprinidae) from cytochrome $b$ sequences. Copeia 2002:665-678.

Durham, B.W., and G.R. Wilde. 2005. Relationship between hatch date and first-summer growth of five species of prairie-stream cyprinids. Environmental Biology of Fishes 72:45-54.

EATON, J.G., AND R.M. SCHELLER. 1996. Effects of climate warming on fish thermal habitat in streams of the United States. Limnology and Oceanography 41: 1109-1115.

Edwards, R.W., J.W. Densem, and P.A. Russell. 1979. An assessment of the importance of temperature as a factor controlling the growth rate of brown trout in streams. Journal of Animal Ecology 48:501-507.

ELLiotT, J.M. 1975. The growth rate of brown trout (Salmo trutta L.) fed on maximum rations. Journal of Animal Ecology 44:805-821.

Elliott, J.M., M.A. Hurley, And J.D. Allonby. 1996. A functional model for maximum growth of immature stone-loach, Barbatula barbatula, from three populations in north-west England. Freshwater Biology 36:547-554

Elliott, J.M., M.A. Hurley, and R.J. Fryer. 1995. A new, improved growth model for brown trout, Salmo trutta. Functional Ecology 9:290-298.

FRY, F.E.J. 1947. Effects of the environment on animal activity. Publications of the Ontario Fisheries Research Laboratory 68:5-62.

1967. The effect of environmental factors on the physiology of fish. Pages 1-98 in W.S. Hoar and D.J. Randall, editors, Fish physiology. Volume 6, Environmental relations and behavior. Academic Press, San Diego, CA. 559 pp.

Hoar, W.S. 1956. Photoperiodism and thermal resistance of goldfish. Nature 178:364-365.

Jobling, M. 1994. Fish bioenergetics. Chapman and Hall, London. 307 pp.

Johnson, J.B., M.C. Belk, And D.K. ShiozaWa. 1995. Age, growth, and reproduction of leatherside chub (Gila copei). Great Basin Naturalist 55:183-187.

Johnson, J.B., T.E. Dowling, And M.C. Belk. 2004. Neglected taxonomy of rare desert fishes: congruent evidence for two species of leatherside chub. Systematic Biology 53:841-855.

Johnson, J.B., And S. Jordan. 2000. Phylogenetic divergence in leatherside chub (Gila copei) inferred from mitochondrial cytochrome $b$ sequences. Molecular Ecology 9:1029-1035.

Keleher, C.J., AND F.J. Rahel. 1996. Thermal limits to salmonid distributions in the Rocky Mountain region and potential habitat loss due to global warming: a geographic information system (GIS) approach. Transactions of the American Fisheries Society 125: $1-13$.

Kowalski, K.T., J.P. Schubaur, C.L. ScotT, and J.R. SPOTILA. 1978. Interspecific and seasonal differences in temperature tolerances of stream fish. Journal of Thermal Biology 3:105-108.

Levinton, J.S. 1983. The latitudinal compensation hypothesis: growth data and a model of latitudinal growth differentiation based upon energy budgets. I. Interspecific comparison of Ophryotrocha (Polychaeta: Dorvilleidae). Biological Bulletin 165:686-698. 
Loeb, J., AND R. Wasteneys. 1912. On the adaptation of fish (Fundulus) to higher temperatures. Journal of Experimental Zoology 12:543-557.

Lohr, S.C., P.A. Byorth, C.M. KaYa, and W.P. Dwyer. 1996. High-temperature tolerances of fluvial Arctic grayling and comparisons with summer river temperatures of the Big Hole River, Montana. Transactions of the American Fisheries Society 125:933939.

LutTerschmidt, W.I., And V.H. Hutchison. 1997. The critical thermal maximum: history and critique. Canadian Journal of Zoology 75:1561-1574.

Matthews, W.J. 1986. Geographic variation in thermal tolerance of a widespread minnow Notropis lutrensis of the North American Mid-West. Journal of Fish Biology 28:407-417.

McHugh, P., AND P. Budy. 2005. An experimental evaluation of competitive and thermal effects on brown trout (Salmo trutta) and Bonneville cutthroat trout (Oncorhynchus clarkii utah) performance along an altitudinal gradient. Canadian Journal of Fisheries and Aquatic Sciences 62:2784-2795.

Mills, C.A. 1991. Reproduction and life history. Pages 483-508 in I.S. Winfield and J.S. Nelson, editors, Cyprinid fishes: systematics, biology, and exploitation. Chapman and Hall, London. 667 pp.

Mills, M.D., R.B. Rader, AND M.C. BELK. 2004. Complex interactions between native and invasive fish: the simultaneous effects of multiple negative interactions. Oecologia 141:713-721.

MincKLEY, W.L., AND M.E. Douglas. 1991. Discovery and extinction of western fishes: a blink of the eye in geologic time. Pages 7-18 in W.L. Minckley and J.E. Deacon, editors, Battle against extinction: native fish management in the American West. University of London Press, Tucson, AZ. 535 pp.

Modde, T., R.T. Muth, and G.B. Haines. 2001. Floodplain wetland suitability, access, and potential use by juvenile razorback suckers in the Middle Green River, Utah. Transactions of the American Fisheries Society 130:1095-1105.

NADOlski, B., AND P. Thompson. 2004. Leatherside chub (Gila copei) distributional surveys in northern Utah, 2003. Utah Division of Wildlife Resources Publication number 04-04.

Olsen, D.G., AND M.C. BELK. 2005. Relationship of diurnal habitat use of native stream fishes of the eastern Great Basin to presence of introduced salmonids. Western North American Naturalist 65:501-506.

Ospina, A.F., AND C. Mora. 2004. Effect of body size on reef fish tolerance to extreme low and high temperatures. Environmental Biology of Fishes 70:339-343.

Отто, R.G. 1974. The effects of acclimation to cyclic thermal regimes on heat tolerance of the western mosquitofish. Transactions of the American Fisheries Society 103:331-335.

Paladino, F.V., J.R. Spotila, J.P. Schubauer, and K.T. KOWALSKI. 1980. The critical thermal maximum: a technique used to elucidate physiological stress and adaptation in fishes. Revue Canadienne de Biologie 39:115-122.

Petricorena, Z.L.C., AND G.N. Somero. 2007. Biochemical adaptations of notothenioid fishes: comparisons between cold temperate South American and New Zealand species and Antarctic species. Comparative Biochemistry and Physiology - Part A: Molecular and Integrative Physiology 147:799-807.
Quist, M.C., W.A. Hubert, And D.J. Isaak. 2004. Fish assemblage structure and relations with environmental conditions in a Rocky Mountain watershed. Canadian Journal of Zoology 82:1554-1565.

Ricker, W.E. 1979. Growth rates and models. Pages 677-743 in W.S. Hoar, D.J. Randall, and J.R. Brett, editors, Fish physiology. Volume 8, Bioenergetics and growth. Academic Press, New York. 786 pp.

Robinson, A.T., AND M.R. ChILDS. 2001. Juvenile growth of native fishes in the Little Colorado River and in a thermally modified portion of the Colorado River. North American Journal of Fisheries Management 21:809-815.

Rodnick, K.J., A.K. Gamperl, K.R. Lizars, M.T. BenNetT, R.N. Rausch, and E.R. KeEley. 2004. Thermal tolerance and metabolic physiology among redband trout populations in south-eastern Oregon. Journal of Fish Biology 64:310-335.

Schrank, A.J., F.J. Rahel, and H.C. Johnstone. 2003. Evaluating laboratory-derived thermal criteria in the field: an example involving Bonneville cutthroat trout. Transactions of the American Fisheries Society 132:100-109.

Selong, J.H., T.E. McMahon, A.V. Zale, and F.T. BarROWS. 2001. Effect of temperature on growth and survival of bull trout, with application of an improved method for determining thermal tolerance in fishes. Transactions of the American Fisheries Society 130:1026-1037.

Shuter, B.J., AND J.R. Post. 1990. Climate, population viability, and the zoogeography of temperate fishes. Transactions of the American Fisheries Society 119: 314-336.

Sigler, W.F., AND J.W. SigLER. 1987. Fishes of the Great Basin, a natural history. University of Nevada Press, Reno. 425 pp.

Smale, M.A., AND C.F. Rabeni. 1995. Hypoxia and hyperthermia tolerances of headwater stream fishes. Transactions of the American Fisheries Society 124:698710.

SPSS, INC. 2004. SPSS ${ }^{\circledR}$ base 13.0 for Windows ${ }^{\mathrm{TM}}$ user's guide. SPSS, Inc., Chicago, IL. 828 pp.

Takle, J.C.C., T.L. Beitinger, and K.L. Dickson. 1983. Effect of the aquatic herbicide Endothal on the critical thermal maximum of red shiner, Notropis lutrensis. Bulletin of Environmental Contaminants and Toxicology 31:512-517.

Tyler, A.V. 1966. Some lethal temperature relations of two minnows of the genus Chrosomus. Canadian Journal of Zoology 44:349-364.

Wagner, E.J., R.E. Arndt, And M. Brough. 2001. Comparative tolerance of four stocks of cutthroat trout to extremes in temperature, salinity, and hypoxia. Western North American Naturalist 61:434-444.

Walser, C.A., M.C. Belk, and D.K. Shiozawa. 1999. Habitat use of leatherside chub (Gila copei) in the presence of predatory brown trout (Salmo trutta). Great Basin Naturalist 59:272-277.

Watenpaugh, D.E., and T.L. Beitinger. 1985. Temperature tolerance of nitrite exposed channel catfish. Transactions of the American Fisheries Society 114: 274-278.

Wehrly, K.E., L. Wang, and M. Mitro. 2007. Fieldbased estimates of thermal tolerance limits for trout: incorporating exposure time and temperature fluctuation. Transactions of the American Fisheries Society 136:365-374. 
Werner, E.E., AND D.J. HaLL. 1988. Ontogenetic habitat shifts in bluegill: the foraging rate-predation risk trade-off. Ecology 69:1352-1366.

Widmer, A.M., C.J. Carveth, S.A. Bonar, and J.R. Simms. 2006. Upper temperature tolerance of loach minnow under acute, chronic, and fluctuating regimes. Transactions of the American Fisheries Society 135:755-762.

Wilson, K.W., AND M.C. BELK. 2001. Habitat characteristics of leatherside chub (Gila copei) at two spatial scales. Western North American Naturalist 61:3642 .

Wilson, K.W., AND L.D. Lentsch. 1998. Current distribution and population abundance of leatherside chub (Gila copei) in the Heber Valley. Utah Division of Wildlife Resources Publication number 98-13. 43 pp.

Received 11 September 2007 Accepted 6 May 2008 